\title{
Beyond the Provisional Nature: Towards a Radial Concept of Practice
}

\author{
Luca Verzelloni \\ Universidade de Coimbra - Portugal \\ verzelloni@ces.uc.pt
}

\begin{abstract}
Practice is one of the key concepts of our time. During the last 30 years, the Practice-Based Studies have spread all over the world. The "rediscovery" of practice has inspired many reflections and empirical researches, contributing to the recent development of the organizational and management studies. This article aims, on the one hand, to reconstruct the debate around the concept of practice and, on the other hand, discuss its meaning, as defined within the PBS. In this paper, it will be argued that practice should be conceived as a "radial concept". This idea, coming from the political science, is the key to explore new universes of meaning and to read and compare the practitioners' activities, the functioning of organizations and the collective learning processes. The paper will introduce the phenomenon of the so-called Observatories of Civil Justice. These interprofessional communities represent a unique window on the Italian judicial system. This case study enables to critically analyse the concept of practice and to highlight its subtypes: experimental practice, solipsistic practice, diffused practice, concerted practice, fixed practice, institutionalized practice.
\end{abstract}

Keywords: practice, practice-based studies, radial concept, institutionalization, observatories of civil justice 


\title{
Além da Natureza Provisória: em Direção de um Conceito de Prática Radial
}

\author{
Luca Verzelloni \\ Universidade de Coimbra - Portugal \\ verzelloni@ces.uc.pt
}

\begin{abstract}
Resumo
Prática é um dos principais conceitos do nosso tempo. Ao longo dos últimos 30 anos, os estudos baseados em prática têm se expandido pelo mundo. A "redescoberta" da prática tem inspirado várias reflexões e estudos empíricos, contribuindo para o desenvolvimento recente dos estudos organizacionais e de gestão. O objetivo deste artigo é, por um lado, de reconstruir o debate sobre o conceito de prática e, por outro, discutir o seu significado como definido nos estudos baseados em prática. Neste artigo, vai ser defendido que prática de ser concebida como um "conceito radial”. Esta ideia, vinda da ciência política, é chave para explore novos universos de significado e para ler e comparar as atividades dos praticantes, o funcionamento das organizações e o processo de aprendizagem coletiva. $\mathrm{O}$ artigo vai introduzir o fenômeno do então chamado Observatórios de Justiça Civil. Estas comunidades inter-profissionais representam uma janela única do sistema de justiça italiano. Este caso possibilita analisar criticamente o conceito de prática e destacar seus subtipos: prática experimental, prática solipicista, prática difusa, prática combinada, prática fixada e prática institucionalizada.
\end{abstract}

Palavras-chave: prática, estudos baseados em prática, conceito radial, institucionalização, observatórios de justiça civil 
Our parents were accustomed to leaf through the pages of an encyclopaedia; unlike them, if we want to know something or understand a concept, in most cases we rely on a search engine on-line. In particular, Google and Yahoo have become a sort of "prophets" of our time.

Typing on a search engine the word "practice", in less than half a second, we have access to over a billion results, articulated in a confused way in a great number of definitions, contributions and references of any kind. The famous image of the Tower of Babel, narrated in Genesis, in some ways describes the complex "world" of languages, ideas and perspective that can be found in the search of information on the concept of practice. This babel of information inevitably generates confusion, overlaps and distortions.

Despite not having a universally accepted definition, practice is one of the key concepts of our time, a sort of fulcrum of many other expressions, which is used many times in the language of everyday life, by the media, in training activities, within the professions, by the scholars from different disciplines, and especially in the broad panorama of organizational and management studies.

In this framework, the article aims, on the one hand, to reconstruct the debate around the concept of practice and, on the other hand, discuss its meaning as defined within the socalled Practice-Based Studies (PBS).

In this paper, it will be argued that the "practice" should be conceived as a "radial concept". This idea, coming from the political science literature, emphasizes the fact that some concepts may have different subtypes (Ostiguy, 1993; Collier \& Mahon, 1993; Schedler, 1999; Lindberg, 2009). The attributes contribute to define the "semantic core" of the primary category. These subtypes are not always clearly distinct and often overlapping each other (Lindberg, 2009). The relationship between the general concept and its attributes is the key to explore new universes of meaning. Defining practice as a "radial concept" has a considerable heuristic value, in order to read and compare the practitioners' activities, the functioning of organizations and the collective learning processes.

The article is divided into seven main sections. The first paragraph will trace the debate's roots, which may be identified in the emergence of a new way of understanding knowledge, understood as something social, situated and procedural (knowing). The second 
paragraph will deal with the rediscovery of practice, which developed as a result of the overcoming of the paradigms of the rationalism, cognitivism and functionalism. The third paragraph will discuss the research questions of this paper, which are based on the idea to move beyond the provisional nature of practice. The fourth paragraph will present the phenomenon of the "Observatories of Civil Justice". This case represents a unique window on the Italian judicial system. The fifth paragraph will discuss the empirical data and it will identify some subtypes of practice. The conclusions will highlight some possible research horizons, based on a new "radial concept" of practice.

The paper is based on the results of a long period of empirical research on the Observatories of Civil Justice. The analysis was launched in 2006. It has considered 19 Observatories, operating in various Italian judicial offices (north, center and south): Avellino, Bari, Bologna, Cagliari, Catania, Florence, Genoa, Messina, Milan, Modena, Naples, Reggio Calabria, Rome, Salerno, Turin, Trento-Rovereto, Trieste, Udine and Verona. From a methodological point of view, the research has used qualitative methods, such as semistructured interviews, participatory observations and documental analysis. The article will refer only to civil sector and will not consider the Italian criminal justice.

\section{From "knowledge" to "knowing"}

The overcoming of the paradigms of the rationalism, cognitivism and functionalism marked an epochal change in the organizational and management studies (Bacharach, Gagliardi, \& Mundell, 1995; Czarniawska \& Joerges, 1995). The idea of an organization as a "machine", which decides in an efficient and effective way, considering all the variables of the situation, has been replaced with the image of a real organization that works by trials and errors (March \& Simon, 1958).

In order to understand the complexity of an organizational context is not enough to analyse its formal structure, but it is necessary to investigate the processes of construction and sharing of knowledge. Knowledge cannot be conceived as a variable kept in the people's minds or in the organizational charts or in the databases, but it is something social, situated and procedural (Gherardi, 200o). 
The discourse about the nature of knowledge dates back to the origin of philosophy and during its evolution has involved numerous authors, from different theoretical perspectives. Far from wanting to trace the entire development of this wide-ranging debate, it is possible to highlight some fundamental steps.

In this sense, Polanyi is undoubtedly a reference point. The author's work is based on a critique of the objectivity, which is prevalent in many fields of knowledge (Polanyi, 1958, 1967). Since every human act involves an evaluation, it is necessary to overcome the idea of the existence of an objective knowledge. Knowledge crystallizes itself in the practical activities. The touch of a pianist, for example, cannot be explained in a manual or in a mathematical formula; acquire the "right touch" is something that can be transmitted to an apprentice only through the master's example. Knowledge has a tacit, aesthetic, intuitive and sensory component, which cannot be explained (Polanyi, 1958; Strati, 1999) - quoting the famous Polanyi's sentence: "we can know more than we can tell" (1967: 4). The same existence of the apprenticeship indicates very clearly that alongside to the abstract, explicit and codified knowledge, there is a tacit, implicit and sensory knowledge, which with the experience becomes part of eyes, ears and hands of the expert practitioner (Goodwin, 1994, 2003; Freidson, 2001).

Secondly, Bourdieu's idea of habitus is an important turning point in the studies on the knowledge (1972). "Knowing" is not only an individual process, but also a social activity. People develop a specific "sens pratique" (Bourdieu, 1980). Like a chess player, every person adapts her/his role to the real-life circumstances. In this sense, knowledge is a "symbolic capital" founded on social interaction.

Thirdly, it is necessary to remember also the Suchman's concept of "situated action" (1987). Knowledge cannot be considered as something abstract and decontextualized, but it has a situated dimension. Each action course depends on the development of the socialmaterial circumstances. Knowledge is continuously created and recreated in a complex microcosm of actors, technologies and socio-material artefacts (Suchman, 1987).

Finally, in the literature, it is possible to identify five types of knowledge: embodied, embedded, embrained, encultured and encoded (Collins, 1993). Blackler has proposed to switch from the study of "knowledge" to the study of "knowing" (1995). The author has outlined five characteristics of this process: 
- knowing as mediated (by language, technology, collaboration and control);

- knowing as situated (in a specific time and space);

- knowing as provisional (constantly changing);

- knowing as pragmatic (purposive and object-oriented);

- knowing as contested (in conflicts between individuals).

Knowledge is created and re-created through the processes of individual and collective learning (Argyris \& Schön, 1978). Knowledge, in fact, is intrinsically linked to the practical action (knowing-in-practice) (Gherardi, 2000, 2006) and individuals develop a specific “competence-to-act” through their mutual interactions (Gherardi \& Nicolini, 2002).

\section{The Rediscovery of Practice}

In the light of these considerations, during the last 30 years, the so-called "PracticeBased Studies" (henceforth also PBS) have spread all over the world. These approaches - in the plural form - have become a sort of "bandwagon" (Fujimura, 1988; Corradi et al., 2010).

The rediscovery of practice - a concept with an ancient and deeply rooted sociological and philosophical tradition, which includes, among others: phenomenological sociology (Schütz, 1962), symbolic interactionism (Mead, 1934), ethnomethodology (Garfinkel, 1967), social praxeology (Bourdieu, 1972), structuration theory (Giddens, 1984), actor-network theory (Latour, 1987; Law, 1987) - which followed the "practice turn” (Schatzki, Knorr-Cetina, \& von Savigny, 2001) or the "re-turn to practice" (Miettinen, Samra-Fredericks, \& Yanow, 2009), has inspired many reflections and empirical researches, contributing to the recent development of the organizational and management studies.

The dimension of practice has been "translated" in different ways (Corradi et al., 2010; Antonacopoulou, 2015):

- “practice-based standpoint” (Brown \& Duguid, 1991);

- “workbased” or "practice-based learning” (Raelin, 1997; Billett, 2001);

- "practice as what people do" (Pickering, 1990);

- "practice lens" and "practice-oriented research" (Orlikowski, 200o); 
- "knowing in practice" (Gherardi, 2000; Orlikowski, 2002);

- "practice-based perspective” (Sole \& Edmondson, 2002);

- "practice-based approaches" (Carlile, 2002; Yanow, 2004);

- "strategy as practice" (Jarzabkowski, 2005; Whittington, 2006).

Beyond the different "labels", the concept of practice is the "topos that ties the knowing to the doing" (Gherardi, 2006: 19). This notion, which derived from the Latin pràctica and from the Ancient Greek pràktiké, is a particularly effective "narrative expedient" to symbolize materiality, fabrication, manual skill, movement and competence-to-act (Gherardi, 2001, p. 136; Nicolini, Gherardi \& Yanow, 2003). Practice is a polysemic word (Strati, 2007; Antonacopoulou \& Pesqueux, 2010), or rather, an "umbrella concept" (Gherardi, 2006, p. 19).

The common meaning of "practice" has a plurality of acceptations (Corradi et al., 2010, p. 279):

- a learning method;

- an occupation or field of activity;

- the way something is done.

In the academic debate, the notion of practice was used simultaneously as an "empirical object" and as a "way of seeing" the processes of organizational learning (Corradi et al., 2010). Practice is both the field where observe the everyday activities of practitioners, that an epistemology (Raelin, 2007) - as explained effectively by Cohen (1996), who introduced the distinction between "theories of action" and "theories of praxis" - to explore the "social orderliness of local settings" (Garfinkel, 1967; Rawls, 2000: 547; Fox, 2006).

In general, Gherardi has defined the concept of practice as: "a mode, relatively stable in time and socially recognized, of ordering heterogeneous items into a coherent set" (2006: 34). In this sense, there are no distinctions among doing, thinking, deciding, knowing, organizing, learning, etc. People learn-by-doing, in the mistakes, by repetition, developing and testing new ways of practicing.

Through the processes of legitimate participation (Lave, Wenger, 1991), the newcomers are socialized to practice and they become part of the social group in which operate (Becker, 1953). Every organizational context is a "constellation of interconnected practices" (Gherardi \& Nicolini, 2002). 
Despite the criticism, the concept of "community of practice" (CoP) has influenced the entire spectrum of studies on organizational learning (Lave, Wenger, 1991; Wenger, 1998; Brown, Duguid, 2001; Swan, Scarbrough, \& Robertson 2002; Contu \& Willmot, 2003; Roberts, 2006; Amin \& Roberts, 2008). As defined by Wenger: "communities of practice are groups of people who share a concern or a passion for something they do and learn how to do it better as they interact regularly" (Wenger, 1998, p. 84). In the literature, there are various definitions and applications of the concept of community of practice. Amin and Roberts have identified four basic varieties of CoPs: craft/task based (aesthetic, kinaesthetic and embodied knowledge); professional (specialised knowledge); expert/creative (expert knowledge); virtual (codified and tacit knowledge) (Amin \& Roberts 2008, p. 357).

In this sense, the discursive practices are fundamental to analyse human behaviour. The language, in fact, is the basis of learning (Vygotskij, 1934; Wittgenstein, 1953), because "it is not only the expression of social relations; it is also the medium for their creation" (Czarniawska-Joerges, 1991; Gherardi, 2006: 23).

In general, every field of practice is an "actor network", which it is composed by human and non-human actors (Callon, 1987; Latour, 1987), connected together in "ecologies of sociomaterial relations" (Fujimura, 1995). Artefacts, texts, rules and technologies act as "material intermediaries" (Law, 1987).

\section{Beyond the Provisional Nature of Practice}

The concept of practice is usually conceived as something provisional and ephemeral. People build a texture of practices that is ever changing. Practice, as defined within the PBS, is "relatively stable" (Gherardi, 2006), being constantly undermined by the activity of the practitioners.

In this sense, the description of a practice is extremely difficult, because it looks like to take a photo of a moving object, or in other words, to get a freeze-frame shot. Practices are developed by repetition: over time, some practices change, others disappear and being replaced or forgotten. These "circuits of reproduction" involve new and old practices, connecting each other practices, "proto-practices" and “ex-practices” (Pantzar \& Shove, 2006). 
However, each practice is always inserted into a specific cultural-historical context. As highlighted by the Cultural-Historical Activity Theory (Engeström, 1987; Blackler, 1995; Miettinen \& Virkkunen, 2005) and by the Soviet Cultural-Historical Psychology (Vygotskij, 1934; Leont'ev, 1981), it is necessary to consider the "system of activities". This system is a social construction, rooted in a particular time and space; it includes objects, subjects, mediating artefacts (as signs and tools), rules, communities and division of labour (Engeström, 1987). In the light of these considerations, since not all practices have a temporary nature, this article raises some research questions: is the concept of practice able to include both provisional and institutionalized practices? How is it possible to distinguish the practices? And, in general terms, how is it possible to redefine the concept of practice?

\section{The Observatories of Civil Justice}

\section{The context: a never-ending season of reforms}

Over the past 30 years, several factors had a negative impact on the Italian judicial system, such as: the increasing rates of litigation, the lack of human, financial and material resources, the unreasonable duration of the judicial proceedings and the atmosphere of distrust of the citizens (Castelli et al., 2014).

In recent years, European Union, Council of Europe, World Bank and OECD have put great pressure on the Italian government to introduce some judicial reforms to improve efficiency and quality of justice (Piana, 2016). The Bank of Italy has estimated that the overcoming of these difficulties would represent a gain of more than a percentage point of the national GDP. This topic has established itself into the public debate and it has influenced the political agenda.

In the last 20 years, 22 major reforms of the Code of Civil Procedures (c.c.p.) have been introduced by the 13 Governments, which have followed each other in Italy. In particular, from 1995 to 1998, 10 major reforms were adopted. These changes have been so fast, repeated and significant that some authors have spoken of a "tsunami of civil justice reforms" (Costantino, 2005-a: 1167). Some articles of the Code have been changed several times: for example, the article 420 c.c.p. on the labour proceedings has been rewritten 3 times in the space of 22 months. 
This never-ending season of reforms has had a direct impact on the legal professionals. In particular, lawyers and judges were constantly asked to adapt their activities to the changes of the "rules of the game", with obvious repercussions on courts' functioning.

The issue is part of a broader discussion. According to several authors, some of the gravest difficulties of the Italian judicial system derive from organizational problems (Di Federico, 1975, 2008; Zan, 2003, 2011; Marchesi, 2003; Biavati et al., 2008; Verzelloni, 2009; Piana, 2016). In particular, the Italian judicial offices often look like a condominium (Zan, 2003), or an island archipelago, populated by various practitioners: judges, clerks, lawyers, etc. - all of them operating independently. In these contexts, there are not collective learning occasions and the legal professionals are comparable to monads, who produce autonomous and solipsistic interpretations of the written rules (Verzelloni, 2009).

\section{Finding common solutions}

The repeated changes of the Code of Civil Procedure (Box 1) have pushed - and continue to push - many practitioners (especially judges, lawyers and clerks) to take part in the meetings of the Observatories of Civil Justice (Caponi, 2003; Costantino, 2005-b; Verzelloni, 2009; Berti, 2011). The "Observatories" - as these entities define themselves - are spontaneous groups that have been developed from the bottom-up in various Italian judicial offices (Box 2).

"We started in 1994, to discuss the reform of the Code that
would take effect in 1995. We wanted to reflect on how the
rules would change our work organization. [...] Today, things
are not very different, due to the flow of new regulations".

Box 1. Interview with a lawyer of the Observatory of Bologna.

"The Observatories are spontaneous aggregations of judges
and lawyers, who are tired of working under bad conditions. To
improve our work, we can no longer operate separated from
each other. [...] The idea is to try to bring together those
who want to enhance the dignity of their work. [...]
The Observatory is a «cultural engine»".

Box 2. Interview with a judge of the Observatory of Naples. 
The idea of the Observatories appeared in the first part of the 9o's. Since 1993 -the year of foundation of the first Observatory of Milan - these experiences have spread in many other courts: currently, there are at least 30 Observatories. The composition is very variable, but always includes lawyers and judges.

These "interprofessional communities of practice" represent a local functional response to the everyday problems faced by the operators. The Observatories have created a space for discussion, in a more or less structured way, in order to find common solutions (Box 3). On the one hand, in fact, the Observatories represent a place where the practitioners can overcome their isolation and share their interpretative and behavioural practices. On the other hand, the Observatories aim to define some "virtuous practices", in order to improve the professional activities and the functioning of courts (Box 4-5).

\section{"The Observatory started with us, judges. [...] We began to discuss with the lawyers and the court clerks in order to find common solutions that would allow us to work".}

Box 3. Interview with a judge of the Observatory of Reggio Calabria.

"The premise is that things work out badly, but we can make
them work better [...] eliminating our self-reference. [...] We
all must be involved in the discussion. We have to accept the
idea that we are all part of the same organization".

Box 4. Interview with a judge of the Observatory of Cagliari.

"The purpose of the Observatory is to seek virtuous practices,
in order to do a better work. [...] It is not possible that the
same injunction is rejected in a room and accepted next door".

Box 5. Interview with a lawyer of the Observatory of Bari.

The Observatories deal with many activities, including: organize workshops, archive the local jurisprudence and elaborate questionnaires on different subjects. But the most significant activity - with respect to the objectives of this paper - is the elaboration of the 
"hearing protocols". This process is central to the life of these communities and, in many cases, justifies their existence.

\section{The hearing protocols}

The "hearing protocols" - as they are called by the members of the Observatories - are documents that collect and comment some interpretative and behavioural practices, defined as virtuous by the same operators. These documents are very different from the protocols used in medicine, biochemistry and biology (Lynch, 2002), since they are not binding, not even in terms of professional ethics, and they only refer to the local court in which they were adopted.

At the national level, there are more than 90 hearing protocols. The first document of this kind was made in Salerno in 2002. Some Observatories have developed various protocols.

These texts deal with various issues, some general as, for example: conduct of the hearings (Box 6); priorities of treatment; minutes; attorneys' fees; notifications; telematics communications; structure of acts of defenders and judges. And others highly specialised issues, such as: testimony of minors (Box 7); concessions in cases of conflictual separation; compensation for damage caused by road accidents; executions; bankruptcies; leases; labour and social security.

"Article 4. Both the judge and the defenders will put great care to comply with the time fixed for the beginning of a hearing and for dealing with each proceeding. [...] Article 11. Judges and defenders will take care to come to the hearing with an actual knowledge of the case, so as to: ensure the effective treatment of the issues relevant to the proceedings; that the decision at the hearing is made with due priority to substantive and procedural matters".

Box 6. Excerpt of the hearing protocol of the Observatory of Modena (2007).

"Article 2. The testimony of a minor should be organised in a way that prevents any exasperation of the conflict and, in any case, during a scheduled hearing, to be organised preferably outside school hours, in a suitable environment and behind closed doors. [...] Article 5. The hearing will take place only in the presence of the minor, the titular judge, the possible 
auxiliary and, if such is appointed, defence attorney of the minor or the minor's curator. In order to avoid constraints, it does not seem appropriate to consider the presence of the parties and of the defence attorneys".

Box 7. Excerpt from the hearing protocol on the subject of minors of the Observatory of Milan (2007).

The drafting of these documents is very often a complex negotiation process. In this sense, the Observatories are a place of mediation, in which the professional divisions are put aside (Box 8).

"We discuss all the time, but in the end we come out with a common solution. This is the spirit of the Observatories".

Box 8. Interview with a lawyer of the Observatory of Naples.

Although not binding, these protocols represent "cultural instruments" with a strong symbolic value. Given their covenantal nature, in some local contexts the protocols are not simple catalogues of rules of "good behaviour", but they are also "accountability tools", even if informal, in order to evaluate and, potentially, to sanction, under the aspect of reputation, those who do not operate in the agreed manner (Box 9).

"With the protocol, we have mainly obtained some "cultural
results». We discussed and we understood that the problems
were in the management of hearings. [...] Now there is a sort of
"social stigma» against judges who run the hearing in a
different manner from the one recommended in the protocol".

Box 9. Interview with a judge of the Observatory of Rome.

Over the time, some hearing protocols have assumed a considerable importance at the national level, so as to be recognized by the Supreme Court of Cassation and to inspire some reforms introduced by the Italian Parliament. In some cases, the practices, as fixed in the protocols, have become national laws and thus binding on all operators. In particular, it should be remembered: 
- the so-called "tables" for the liquidation of non-pecuniary damage (Observatory of Milan), recognized by the "United sections" of the Italian Supreme Court (judgment 12408/2011 and order 134/2013);

- the so-called "Office for Trials" (Observatory of Florence), established by article 50 of the Decree-Law 90/2014, converted in Law 114/2014;

- some provisions related to the "On-Line Civil Trial" (various Observatories), included in Decree-Law 179/2012, converted in Law 221/2012 and Decree-Law 83/2015, converted in Law 132/2015;

- the so-called "calendar of the trial" (Observatory of Florence), introduced by Law 69/2009 and Decree-Law 138/2011.

\section{Discussion}

The Observatories are a multifaceted entity, which lends itself to different interpretations. In light of the research questions of this article, the case study enables to critically analyse the concept of practice, as defined within the PBS.

This experience highlights at least six different subtypes of practice. These dimensions identify some aspects that coexist within the general concept of practice. The six attributes should be considered exclusively as "interpretive tools" to develop comparisons.

Firstly, practice can be "experimental". The long season of judicial reforms has had a negative impact on the Italian legal professionals. In general, any change - not only a new legislation - requires a transition period. During this phase, the operators test new practices, in order to adapt their working activities. These practices are, by definition, provisional and ephemeral. This dimension is particularly evident in the legal context, but it is applicable whenever people have to change their usual ways of doing things.

Secondly, practice can be "solipsistic". As mentioned in the previous pages, one of the main problems of the Italian judicial system is the fact that some courts are comparable to a condominium, where there are no collective learning opportunities. Beyond the Italian case, it is possible to identify another subtype of practice. In every organization, in fact, operators adopt some stable and repeated practices, which are intrinsically individual. On some 
occasions, these practices are not even known by the other practitioners and they represent a sort of "personal treasure".

Thirdly, practice can be "diffused". The Observatories are "interprofessional communities of practice": places of encounter and exchange, where the operators can overcome their isolation and share their interpretative and behavioural practices. In the organizations, there are always practices of this type, which are transferred from practitioner to practitioner through language and imitation.

Fourthly, practice can be "concerted". The Observatories aim to develop "virtuous practices", in order to overcome the problems faced by courts. The "solutions" are made through complex processes of negotiation among practitioners. These practices are not only "socially recognized" (Gherardi, 2006:34), but they are conceived as the "appropriate” ways of doing things. In general, concerted practices are result both of explicit and implicit negotiations. These processes can be associated with collective/organizational learning phenomena.

Fifthly, practice can be "fixed". The hearing protocols represent "repertories" of stable practices. These documents are closely linked to the contexts in which they were written. As a result of agreements, the protocols may redefine the boundaries of individual discretion. These practices are not ephemeral and temporary, but conversely they are "internalized" by the operators, are potentially included in manuals and internal procedures, and they are taught to newcomers.

Sixthly, practice can be "institutionalized". Some hearing protocols have been transposed into the national legislation. Practices have become binding on all operators, extending their scope beyond the court in which they were defined. In general, these practices overcome organizational boundaries and they spread across society. The practices of this kind turn into "rules" for behaviour.

Figure 1 shows the six subtypes of practice. These attributes are not strictly separated. Each subtype, in fact, has a common semantic space with other categories. The attributes are represented as a chain around the concept of practice. 


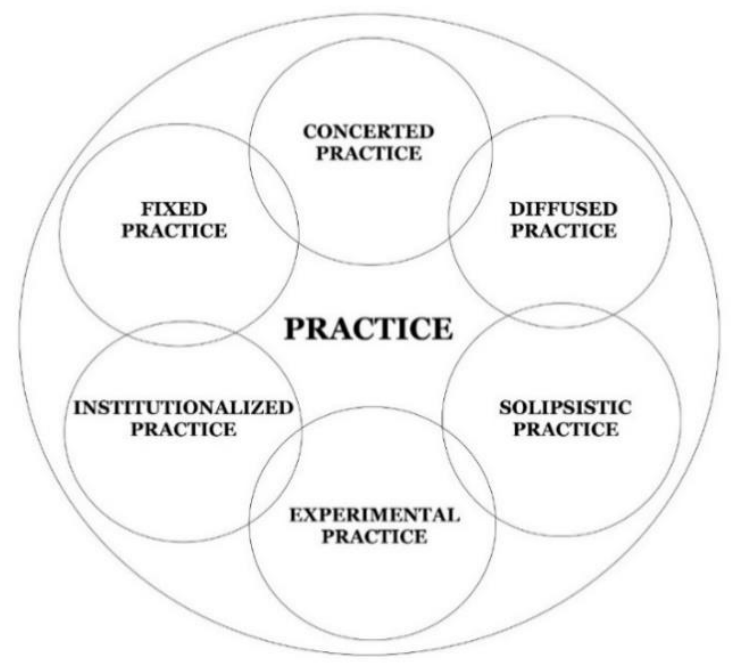

Figure 1. The radial concept of practice and its subtypes.

The subtypes can also be conceived as different stages of the institutionalization of practice (Figure 2). This path is not deterministic and does not follow a predetermined order: for example, a practice can remain "experimental" and be forgotten; another can become "diffused", but never become "concerted"; another can also move from "solipsistic" to "fixed". These phases are not automatic, but depend on a number of factors. This process is cyclical: an institutionalized practice can also turn into a new experimental practice.

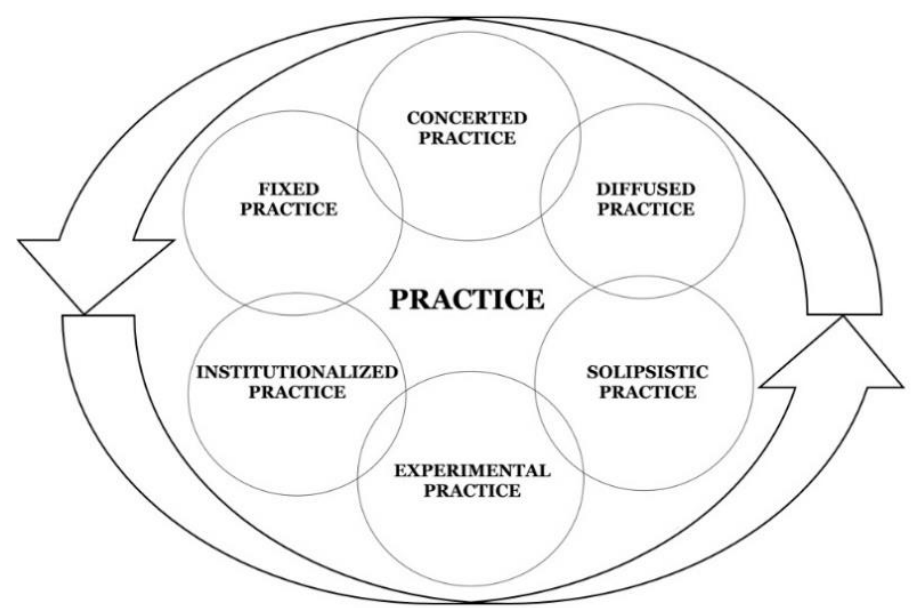

Figure 2. The phases of the institutionalization process.

The institutionalization process includes different levels of analysis: individual practitioner (experimental and solipsistic practices), social group (diffused and concerted 
practices), organization (or organizations) (concerted and fixed practices) and society as a whole (institutionalized practices) (Figure 3).

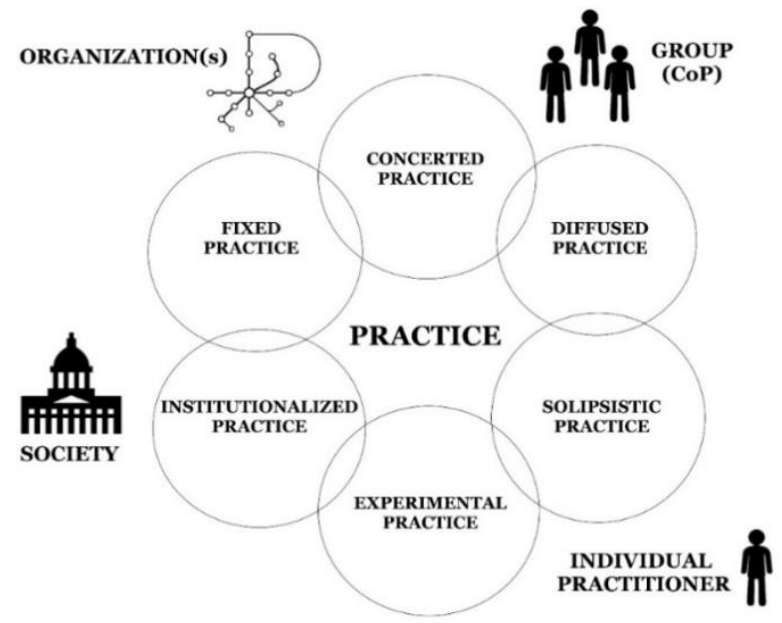

Figure 3. Different levels of practice.

\section{Concluding Remarks}

The article has discussed the concept of practice, as defined within the Practice-Based Studies. Since not all practices have the same nature, the main conclusion of this paper is that it is necessary to overcome the actual representation of practice, understood only as something provisional and temporary.

The article proposes to consider the practice as a "radial concept". This idea leads to rethink the macro concept of practice. In this sense, the case of the Observatories of Civil Justice highlights six different subtypes of practice:

- experimental practice;

- solipsistic practice;

- diffused practice;

- concerted practice;

- fixed practice;

- institutionalized practice.

The subtypes are connected each other and they represent, at the same time, different steps of the institutionalization of practice. The model considers four levels: individual 
practitioner, social group, organizations and society. However, this process should not be conceived as something predetermined. Practices, in fact, have different stories and trajectories: not all practices pass from one stage to another and not all practices are institutionalized.

In conclusion, this exploratory paper aims to generate a debate on the "radial concept" of practice. This perspective opens new research horizons in the fields of organizational and management studies. In the first place, it is necessary to conduct comparative studies, both in public and private sectors, to test the validity of the six subtypes of practices. In the second place, it is opportune to evaluate the possibility to introduce some semantic changes, so as to complete the wide spectrum of meanings of the concept of practice. Finally, it is essential to analyse the factors that contribute to the institutionalization of practice. In this sense, the subtypes allow to split the process, in order to consider its effects over time. 


\section{References}

Amin, A., \&Roberts, J. (2008). Knowing in Action: Beyond Communities of Practice. Research Policy, 37(2).

Antonacopoulou, E.(2015). One More Time: What is Practice? Teoria e Prática em Administração, 5(2), 2015.

Antonacopoulou, E., \& Pesqueux, Y. (2010). The practice of socialization and the socialization of practice. Society and Business Review, 5(1).

Argyris, C., \& Schön, D. (1978). Organizational Learning: A theory-in-action perspective. Massachusetts: Addison-Wesley.

Bacharach, S. B., Gagliardi, P., \& Mundell, B. (Eds.) (1995). Studies of Organizations in the European Tradition. Greenwich: Jai Press.

Becker, H. (1953). Becoming a Marihuana User. American Journal of Sociology, 59(3).

Berti, V. G. (Ed.). (2012). Gli osservatori sulla giustizia civile e i protocolli d'udienza. Bologna: Il Mulino,.

Biavati, P., Guarnieri, C., Orlandi, R.,\& Zanon, N. (2008). La giustizia civile e penale in Italia: aspetti ordinamentali e organizzativi. Bologna: Il Mulino.

Billett, S. (2001).Knowing in practice: re-conceptualising vocational expertise. Learning and Instruction, 11( 6).

Blackler, F. (1995). Knowledge, knowledge work and organizations: an overview and interpretation. Organization studies, 16(6).

Bourdieu, P. (1972). Esquisse d'une théorie de la pratique. Paris: Edition du Seuil.

Bourdieu, P. (1980). Le sens pratique, Paris: Les Editions de Minuit.

Brown, J. S., \& Duguid, P. (1991). Organizational Learning and Communities of Practice: Toward a Unified View of Working, Learning and Innovation. Organization Science, 2. 
Brown, J. S., \& Duguid, P. (2000). The Social Life of Information. Boston: Harvard Business School Press.

Callon, M. (1987). Some elements of a Sociology of Translation: domestication of the scallops and the fishermen of St Brieuc Bay. In J. Law (Ed.) Power, Action and Belief. London: Routledge \& Kegan Paul.

Caponi, R. (2003). Per gli Osservatori sulla Giustizia Civile. Il Foro Italiano, 11.

Carlile, P. R. (2002). A Pragmatic view of knowledge and boundaries: Boundary objects in new product development. Organization Science, 13.

Castelli, C., Liccardo, P., Melillo, G., Piana, D., \& Verzelloni, L. (Eds.) (2014). Giustizia, territori e governo dell'innovazione. Roma: Carocci.

Cohen, I. J. (1996). Theories of Action and Praxis. In B. S. Turner (Ed.) The Blackwell Companion to Social Theory. Cambridge: Blackwell Publishers.

Collier, D., \& Mahon, J. E. (1993). Conceptual “Stretching” Revisited: adapting categories in comparative analysis. The American Political Science Review, 87(4).

Collins, H. (1993). The structure of knowledge. Social Research, 6o.

Contu, A., \& Willmott, H. (2003). Re-embedding situatedness: the importance of power relations in learning theory. Organization Science, 14.

Corradi, G., Gherardi, S., \& Verzelloni, L. (2010). Through the practice lens: where is the bandwagon of Practice-Based Studies heading? Management Learning, 41(3).

Costantino, G.( 2005-a). Considerazioni impolitiche sulla giustizia civile. Questione giustizia, 6.

Costantino, G. (2005-b). Tra processo e organizzazione: per una giustizia civile tempestiva ed efficace. Democrazia e diritto, 43. 
Czarniawska, B., \& Joerges, B. (1995).Winds of organizational change. How ideas translate into objects and actions. In S. Bacharach, P. Gagliardi, \& B.Mundell (Eds.) Research in the sociology of organizations. Greenwich: JAI Press.

Czarniawska-Joerges, B. (1991). Culture is the medium of life. In P. J Frost. et al. (Eds.) Reframing Organizational Culture. Newbury Park: Sage.

Di Federico, G. (2008). Ordinamento giudiziario: uffici giudiziari, CSM e governo della magistratura. Padova: Cedam.

Di Federico, G. (1975). Scienza dell'amministrazione e ordinamento giudiziario. Roma: De Luca.

Engeström, Y. (1987). Learning by expanding: an activity-theoretical approach to developmental research. Helsinki: Orienta-Konsultit.

Fox, S. (2006). Inquiries of every imaginable kind: Ethnomethodology, practical action and the new socially situated learning theory, The Sociological Review, 54(3).

Freidson, E. (2001). Professionalism, the third logic: on a practice of knowledge. Chicago:

University of Chicago Press.

Fujimura, J. (1988). Molecular Biological Bandwagon in Cancer Research: Where Social Worlds Meet. Social Problems, 35(3).

Fujimura, J. (1995). Ecologies of action: recombining genes, molecularizing cancer, and transforming biology. In S. L. Star (Ed.). Ecologies of Knowledge. Albany: University of New York Press.

Garfinkel, H. (1967). Studies in Ethnomethodology. Prentice Hall: Englewood Cliffs.

Gherardi, S. (2000). Practice-based theorizing on learning and knowing in organizations: an introduction. Organization, 7(2). 
Gherardi, S. (2001). From organizational learning to practice-based knowing. Human relations, 54(1).

Gherardi, S. (2006). Organizational Knowledge: The Texture of Organizing. London: Blackwells.

Gherardi, S., \& Nicolini, D. (2002). Learning in a constellation of interconnected practices: canon or dissonance? Journal of Management Studies, 39.

Gherardi, S., Nicolini, D., \& Odella, F. (1998). Toward a social understanding of how people learn in organizations: the notion of situated curriculum. Management Learning, 29(3).

Giddens, A. (1984). The Constitution of Society. Cambridge: Cambridge University Press.

Goodwin C. (1994). Professional Vision. American Anthropologist, 96(3).

Goodwin C. (2003). Il senso del vedere. Roma: Meltemi.

Jarzabkowski, P. (2005). Strategy as Practice: An Activity Perspective. London: Sage.

Latour, B. (1987). Science in Action: how to follow scientists and engineers through society. Cambridge: Harvard University Press.

Lave, J.; Wenger, E. C. (1990). Situated Learning: Legitimate Peripheral Participation. Cambridge: Cambridge University Press.

Law, J. (Ed.). (1987). Power, Action and Belief. London: Routledge \& Kegan Paul.

Leont'ev, A. N. (1981). Problems of the Development of the Mind. Moscow: Progress Publishers.

Lindberg, S. (2009). Byzantine Complexity: Making Sense of Accountability. IPSA Working Paper Series on Concepts and Methods.

Lynch, M. (2002). Protocols, Practice, and the Reproduction of Technique in Molecular Biology. Journal of Sociology, 53(2). 
March, J. G., \& Simon H. A. (1958). Organizations, New York: Wiley.

Marchesi, D. (2003). Litiganti, avvocati e magistrati. Bologna: Il Mulino.

Mead, G. H. (1934). Mind, Self and Society. Chicago: University of Chicago Press.

Miettinen, R., Samra-Fredericks, D.,\& Yanow, D. (2009).Re-turn to Practice: an Introductory Essay, Organization Studies, 30(12).

Miettinen, R., \& Virkkunen, J. (2005). Epistemic objects, artefacts and organizational change. Organization Studies, 12(3).

Nicolini, D., Gherardi, S., \& Yanow, D. (Eds.). (2003). Knowing in Organizations: A PracticeBased Approach. Armonk, NY: M. E. Sharpe.

Orlikowski, W. (2000). Using Technology and Constituting Structures: a Practice Lens for Studying Technology in Organizations. Organization Science.

Orlikowski, W. (2002). Knowing in practice: enacting a collective capability in distributed organizing. Organization Science.

Ostiguy, P. (1993). Democracy: a radial concept? Berkeley: University of California.

Pantzar, M., \& Shove, E. (2006, Jun). Circuits of reproduction and the dynamics of practice in everyday life. Paper presented at: The Second Organization Studies Summer Workshop on 'Re-turn to Practice: Understanding Organization as It Happens', Mykonos.

Piana, D. (2016). Uguale per tutti? Giustizia e cittadini in Italia. Bologna: Il Mulino.

Pickering, A. (1990). Knowledge, Practice and Mere Construction. Social Studies of Science, $20(4)$.

Polanyi, M. (1958). Personal Knowledge. London: Routledge and Kegan Paul.

Polanyi, M. (1967). The tacit dimension. New York: Doubleday.

Raelin, J. A. (1997). A Model of Work-Based Learning. Organization Science, 8(6). 
Raelin, J. A. (2007). Toward an Epistemology of Practice. Academy of Management Learning E Education Journal, 6(4).

Rawls, A. (200o). Harold Garfinkel. In, G. Ritzer (Ed.). The Blackwell Companion to Major Contemporary Social Theorists. Cambridge: Blackwell.

Roberts, J. Limits to Communities of Practice. Journal of Management Studies, 43, 3, 2006.

Schatzki, T. R., Knorr-Cetina, K., \& von Savigny, E. (2001). The Practice Turn in Contemporary Theory. London: Routledge.

Schedler, A. (1999). Conceptualizing Accountability. In , A. Schedler, L. Diamond \& M. F. Plattner (Eds.). The Self-Restraining State: Power and Accountability in New Democracies. Boulder and London: Lynne Rienner.

Schütz, A. (1962). Collected Papers I. Problem of Social Reality. Hague: Nijhoff.

Sole, D., \&Edmondson, A. (2002). Situated Knowledge and learning in dispersed teams. British Journal of Management, 13.

Strati, A. (1999). Organizations and Aesthetics. London: Sage.

Strati, A. (2007). Sensible Knowledge and Practice-Based Learning, Management Learning, $38(1)$.

Suchman, L. A. (1987). Plans and Situated Actions: the problem of human machine communication. Cambridge: Cambridge University Press.

Swan, J., Scarbrough, H., \& Robertson, M. (2002). The construction of Communities of Practice in the management of innovation. Management Learning, 33(4).

Verzelloni, L. (2009). Dietro alla cattedra del giudice. Bologna: Pendragon.

Vygotskij, L. S. (1934). Myslenie i rec. Moskow: Ekon.

Wenger, E. (1998). Communities-of-practice: learning, meaning and identity. New York: Cambridge University Press. 
Whittington, R. (2006). Completing the practice turn in strategy research. Organization Studies.

Wittgenstein, L. (1953). Philosophical Investigations. Oxford: Blackwell.

Yanow, D. (2004). Translating Local Knowledge at Organizational Peripheries. British Journal of Management, 15.

Zan, S. (2003). Fascicoli e tribunali. Bologna: Il Mulino.

Zan, S. (2011). Le organizzazioni complesse. Roma: Carocci.

Submission: $30 / 09 / 2016$ Accepted: 2o/11/2016 